International Journal of Social Sciences and Humanities
Available online at http://sciencescholar.us/journal/index.php/ijssh
Vol. 2 No. 2, August 2018, pages: 214 225
e-ISSN: 2550-7001, p-ISSN: 2550-701X
https://doi.org/10.29332/ijssh.v2n2.167

\title{
Sustainable Energy Development: Its Postulates and Principles in the Community
}

\begin{abstract}
CrossMark
Antonio Vazquez Perez ${ }^{\text {, }}$, Maria Rodriguez Gamez ${ }^{b}$, Antonio Sarmiento Sera c, Raynel Diaz Santos ${ }^{\mathrm{d}}$

Article history: Received 20 March 2018, Accepted in revised form 25 July 2018, Approved 15 August 2018, Available online 17 August 2018

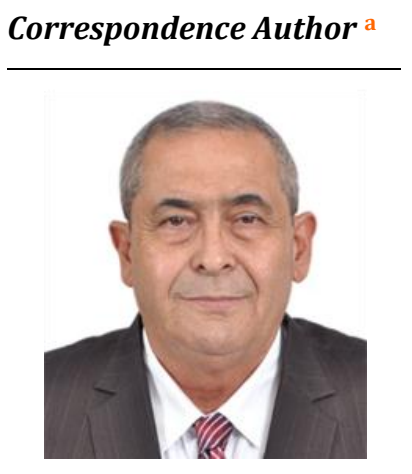

Keywords

Energy development;

Energy;

Legal norm;

Renewable sources;

Sustainability;

Abstract

Although the conditions of the energy scenario have changed in recent years with the introduction of renewable sources, even the international environmental problem continues to be unknown as the more industrialized countries, continue to emit a large number of elements into the atmosphere that together with the processes natural hazards linked to volcanic eruptions, fires between some aspects that today are accelerating the melting of ice from the polar ice caps, other problems associated with the economy are looming; Therefore, it is necessary to evolve from an industry that only produces and stimulates the use of electricity generated based on fossil fuel consumption, towards a diverse, renewable and sustainable energy industry, supported by the use of renewable resources available territorially, which stimulates specific energy consumption and adjusted to the needs and demands of material and environmental quality, under appropriate criteria and parameters of austerity in consumption. The need for the country to undertake the transition to a new national energy base is exposed, which implies the extensive penetration of all forms of use of renewable sources, as the only way to achieve sustainability under the conditions of current technological development, as well as embark on the shortest path towards energy independence and technological sustainability, and it is necessary to reorient the national energy policy, focused on the postulates and principles of sustainable energy development, for which it is necessary to enact a legal rule that explicitly, address protection over the penetration of technologies that take advantage of renewable sources in the energy system.
\end{abstract}

e-ISSN : 2550-7001, $p$-ISSN : 2550-701X ${ }^{\odot}$ Copyright 2018. The Author. SS Journals Published by Universidad Técnica de Manabí. This is an open-access article under the CC BY-SA 4.0 license (https://creativecommons.org/licenses/by-sa/4.0/) All rights reserved.

a Universidad Tecnica de Manabi, FCMFQ, carrera de Ingenieria en construcciones, Portoviejo, Ecuador

b Universidad Tecnica de Manabi, FCMFQ, carrera de Ingenieria en Electricidad, Portoviejo, Ecuador

c Centro de Eficiencia Energetica y energias enovables, (CETER), Cujae, Cuba

d Centro de Investigaciones y Pruebas Electroenergeticas (CIPEL), Cujae, Cuba 


\section{Contents}

Abstract

1. Introduction

2. Research Method

3. Results and Analysis

3.1 Historical background

3.2 Postulates and principles of sustainable energy development....................................................................... 220

3.3 Postulates of sustainable energy development ................................................................................................... 220

3.4 Principles of sustainable energy development.................................................................................................. 221

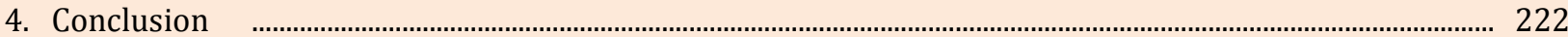

Conflict of interest statement and funding sources.................................................................................................. 222

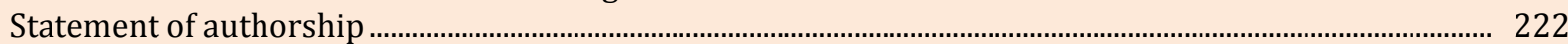

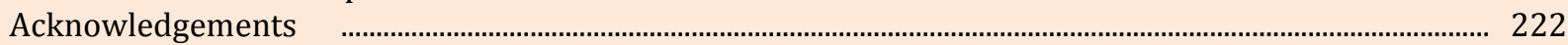

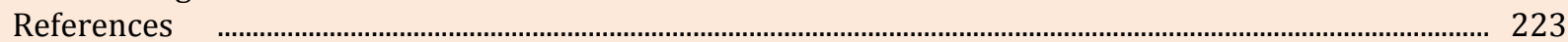

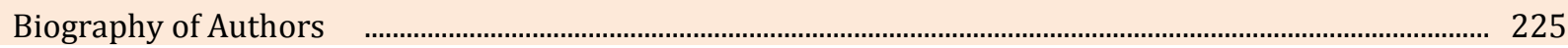

\section{Introduction}

Beyond the arithmetical calculations, the immutable laws of physics and the mathematical models to which the subjects related to the study of the energetic profile are usually helped, it is important to enter into a brief review of the problem from a philosophical point of view and a social vision, that helps to understand the formulation of new integrated solutions to sustainable development policy concepts, based on the use of renewable energy sources.

Of the four and a half billion years of history that the planet has, man has shared with the rest of the creatures the last five hundred thousand years. Before and after its impacts were lethal to the rest of the species, there was evolution and extinction. In geological time every species has a finite time of existence; but it has been demonstrated that the responsibility of the man in front of the process of loss of the biological diversity and the depletion of the natural resources, is given in a rhythm that oscillates between a thousand and ten thousand times faster than the process that occurs of natural form [1].

On this basis, the loss during the 21st century of two thirds of all existing species, the depletion of hydrocarbons and other mineral resources necessary for development is calculated, which in terms of living species, is equivalent to the disappearance produced in the Cretaceous era and it took five million years for the ecological balance to be achieved, that is, five times the age of man on earth [1].

Studying the historical background of this scenario can be analyzed, as from the fifteenth century with the arrival of European man to the lands of America, human aggression reached the limit of exterminating their own species, the most reprehensible feelings were fueled by interests and economic advantages; whole populations were exterminated; unrivaled cultures were truncated in full development, plundered in their values, humiliated in their principles and in parallel a predatory policy of natural resources and the environment is unleashed, which unfortunately continues to this day..

The burgeoning rising bourgeoisie without renouncing the kingdom of heaven lowered its eyes to the earth as never before and cared more for its present, considering man as a simple workforce and insatiable devourer of goods. The turbulence of this period was extended to the sciences and the discoveries were later used by the industry, all of which gave a remarkable boost to the strengthening and economic development, which had its most evident expression times after the industrial revolution in the late eighteenth century [1].

The historical leap in terms of environmental impacts caused by anthropic activity has its origin at the end of the eighteenth century, the industrial revolution meant a strong increase in the demand for raw materials and energy, the most used until then the wood, was displaced by fossil fuels, first by coal, then by oil and natural gas [2].

In 1868, the first legal document known, on a subject related to environmental protection, was brought to light when a request was submitted to the Ministry of Foreign Affairs of the Austro-Hungarian Empire by a group of farmers concerned about the hunt that insectivorous birds were objects before the demand of their

Perez, A. V., Gamez, M. R., Sera, A. S., \& Santos, R. D. (2018). Sustainable energy development: its postulates and principles in the community. International Journal of Social Sciences and Humanities, 2(2), 214-225. https://doi.org/10.29332/ijssh.v2n2.167 
plumage for hats according to Victorian fashion. In it the Emperor was asked to sign an international treaty, for the protection of birds beneficial to agriculture [1].

In this same period 1884 and following the same trend, the Hunting Law was enacted in Cuba, which protected those species of Cuban fauna useful for agriculture, later in the year 1909, the Law of Hunting and Fishing was enacted [1].

At the end of the 19th century, petroleum and nuclear fuels appeared as elements that would facilitate the eternal solution to the problems of development in terms of their energy needs, the design of the prevailing political and economic system, based on an uncontrolled race for consumption, made that these sources be considered as unlimited and infinite, without assuming the physical exhaustion of the reserves of these resources and the environmental impact associated with the intensive exploitation of hydrocarbons and nuclear fuels.

Until then, science had not demonstrated the environmental effects and accelerated depletion of natural resources that had already accumulated the predatory and irresponsible activity of man, therefore neither ethically nor scientifically existed such concerns. Consequently, the main authors of the jump experienced in industrial development, felt puffed up by the scientific knowledge acquired and their technological inventions. They stood as judges and executioners of everything that existed and it did not matter to him to condemn all those who did not respond to his immediate tastes, patterns, and interests, to disappear.

The technological takeoff of industrial society imposed as a paradigm to produce more to have greater benefits, that is, to prioritize the generation of energy over its effects and consequences. The increasingly modern conventional technologies allowed that during the first half of the twentieth century, the consumption of energy to practically immeasurable levels, being the cost of fuels very cheap and affordable. Until the 1970s, energy consumption doubled every ten year period, or in other words, every period of fourteen years, humanity consumed as much energy as its previous history [2].

Already by 1984, a group of German scientists detected signs of deterioration in the forests, although the problem of acid rain was already widely known. In this same year it was reported that the Earth was losing 11 million hectares of forests annually and in 1985 two British scientists reported the discovery of a hole in the ozone layer over Antarctica [1]; but the international inability to strike a balance between development and environmental conservation has already put life on the planet in danger. The irresponsible act of man to achieve an irrational quality of life does not skimp on continuing to waste natural resources that are depleted at an unsustainable pace, leaving behind more pollution and negative impacts.

The serious damage to the natural environment caused by the imperial policies of development, where production and overconsumption of energy has played a decisive role, has meant that beyond the controversial debate on its causality, it has begun to become aware of the finite character of the resources of the biosphere, as well as the need to maintain economic and social development, without compromising the enjoyment of an adequate environment by current and future generations, what has been called modern.

In this ebb of transformations and impacts, a general interest for the protection of the environment was progressively fostered, favoring a paradigm shift that has motivated the birth and development of "Environmental Law" and, as hand-carried, renewable sources of energy shine in its capacity for practical action, as an alternative of adequate solution for achieving the proposed objectives, in order to safeguard the health of the planet and achieve the goals of sustainable development.

However, environmental law as a system of international standards, does not imply a binding nature and therefore not mandatory by the states to comply, based on consensus agreements to achieve certain environmental protection objectives, leaving a marked margin for the initiative and the self-determination of each state, being able to affirm that the normative perspective of its content, does not reach the ordering of the use and improvement of the renewable sources of energy.

From the national point of view there is an environmental legislation headed by Law 81 of 1997; but following the style of International Environmental Law, it has a more proactive and consultative nature of what should and should not be done, not linking criminal measures to non-compliant parties, nor does it contemplate the obligatory nature that individuals can assume in order to undertake certain mitigation measures and reduction of environmental impacts.

On the other hand, the country's energy legislation does not define, order and protect the use of renewable sources, nor regulate the social relationships that derive from the energy services associated with the use of these sources [12], 
Under these conditions, environmental and energy legislation is not very useful, to propitiate a strategic projection endowed with a political vision based on the postulates and principles of sustainable energy development, for which the adequate use of renewable energy sources and their penetration will be inevitable. in the national energy matrix, based on new concepts on the use of natural resources, efficiency, quality and austerity in consumption. The research aims to highlight the need for a legal regulatory framework that encourages the use of renewable energy sources (ERP) and the penetration of technologies linked to Renewable Energy Services (SER) [13], [14].

\section{Research Method}

The development of the investigation was based on an analysis of the historical development of the behavior of the Cuban energy profile, starting from the penetration of electricity in Cuba and its transit through several stages until reaching the distributed generation mode where the introduction of The renewable energies. A review of the literature, historical analysis, logical reasoning and exegetical analysis was carried out, which allowed us to unveil the postulates and principles that should distinguish sustainable energy development based on the use of FREs and the introduction of SER.

\section{Results and Analysis}

\subsection{Historical background}

The first regulation linked to the energetic profile that is recorded in it, is related to the use of solar energy in architecture and dates from ancient Greece; Socrates pointed out that the ideal house should be cool in summer and warm in winter, explaining that "in houses facing south, the sun penetrates the portico in winter, while in summer the solar arc described rises above our heads and by above the roof, so that there is shade "[4].

For thousands of years it was the renewable sources of energy that ensured the development of society, but already at the end of the 18th century with the takeoff of the Industrial Revolution, an energy industry characterized by large generation centers was consolidated, involving a complex and wide process of distribution and transportation of electricity to its final consumption, based first on the use of coal, then the intensive exploitation of oil and more recent use of nuclear energy.

In this scenario, what is essentially technical and what is important from the economic point of view is energy, responding to increasingly high electricity demands that represent greater profits, configuring a social image of fictitious electricity service, while millions of people do not they have access to the service.

The penetration of electrical services in Cuba was marked for history on February 22, 1889, at about 12 and a half, when the electric arc lights that had been turned on for the first time in the Central Park of Havana were turned on. installed there and on Sunday, March 3, the electric lighting in the Central and Isabel "la Católica" parks would be inaugurated, with the service provided from the Tallapiedra plant in Havana, under the auspices of the Spanish American Light and Power Consolidated, the that used Spanish and Creole frontmen to close the business with the Havana City Council and on September 7 of that same year, the public service of electric lighting in the city of Cárdenas in Matanzas was officially inaugurated [5].

In only 5 years later the electrical lighting extends to the cities of Matanzas, Camagüey, and Pinar del Río and in the year 1900 the School of Engineers, Electricians and Architects are created in the University of Havana [5].

On March 26, 1912, the Havana Electric Railway Light and Power Co were formed, in that same year it merged with the Spanish American and centralized all the gas, electricity, ice, water and tram services of the capital and the Tallapiedra plant. On December 10, 1927, in the United States, in accordance with the legislation of the State of Florida, the Cuban Electric Company or the Cuban Electricity Company was created and, as early as 1928, the Monopoly of electric service in Cuba was extended. by the Compañía Cubana de Electricidad, a subsidiary of the American \& Foreign Power Co. (subsidiary, in turn, of the Electric Bond \& Share Co.) [5].

By 1958, the Cuban Electricity Company has increased its installed capacity by almost 4 times compared to the existing capacity in the $1930 \mathrm{~s}$ and has about $10,200 \mathrm{~km}$ of lines of all voltages; but the electric service extends to where it is advantageous economically to the owners of the electric service. Only $56 \%$ of Cuban citizens can enjoy the service and in rural areas, it is practically unknown [5].

Perez, A. V., Gamez, M. R., Sera, A. S., \& Santos, R. D. (2018). Sustainable energy development: its postulates and principles in the community. International Journal of Social Sciences and Humanities, 2(2), 214-225.

https://doi.org/10.29332/ijssh.v2n2.167 
In a tight synthesis on the analysis of the historical development of the energy profile in the country during these years, it can be defined that before, during and after each penetration phase, the role of the regulatory order on the part of the dominant class in function of materializing in a regulated manner each of its purposes, which acquired relevant levels during the penetration of the North American energy monopoly and the emergence and consolidation of the Cuban electric bourgeoisie. Energy begins to be regulated as a simple product of the market, generating more to consume more, regardless of any social and environmental consideration as a right of people. In all this dynamic process energy is reduced to the value of a simple commodity.

On January 1, 1959, the prevailing tyranny is overthrown and in the first twenty years that followed, important conceptual and structural changes will take place in the economic and social life of the nation and, as part of this metamorphosis, energy development will be undertaken, now with a new valuation; For the first time in the history of the country, a redeployment of the role and energy management towards functions of a social nature and not simply mercantilist begins. Electric power begins to stop being considered as a simple product of the market, to become a genuine right at the service of the development of the nation and society.

In August 1960 the Cuban Electricity Company was nationalized and although no specific revolutionary Law was enacted on the energy profile, the first steps were taken in the integral development of the nation and to bring electricity to all corners of the country. Cuban society.

With the help of the member countries of what used to be the Socialist Field, especially the Soviet Union, the National Electroenergetic System (SEN) was created and put into operation by 1973; and in 1989 the generation of electric power had increased by eight times and electrification had reached $95 \%$ of the total population of the country [6].

In the following years, the level achieved in energy development is consolidated; In 1975, Law 1287, the Cuban Electricity Law, [7] was promulgated, which among its objectives presents the guarantee of ordering and regulating the growth of the electricity industry, in order to face the growing demand in function of the economic and social development of the country, extending this vital service to numerous agricultural and industrial facilities throughout the length and breadth of the country [6].

The Law itself begins to regulate the first measures to avoid wastage or inadequate use of energy, recognizing it as a mandatory objective for the entire nation [7] and establishing the need to update and unify the various technical standards that regulate the matter, dispersed until those moments in different laws and dispositions.

In the same year 1975 and in accordance with the provisions of Law 1287, the Regulation of the Electric Service was approved and published, establishing the regulatory bases to achieve the rational use and maximum utilization of the electric power, being necessary the updating and unification of the various regulatory technical norms of the subject [7].

Product of an adverse international political situation, together with the consequences of the resurgence of the economic blockade by the United States of North America, between 1989 and 1993 the gross domestic product of the Island was reduced by half and imports fell by $75 \%$, the oil importation was depressed by $40.6 \%$, having a very severe impact on all the orders of the country's economic and social life for several years [6]. The electrical industry also began to lack spare parts and other components necessary for its operation.

In 1993, an intensive process of recovery of electric generation capacity began, accompanied by a notable increase in the demand for electricity and in 1997 the Cuban Government approved a strategy focused on several objectives, aimed at shaping the efficiency and recover the generation capacity of the SEN [6].

In 2005, the country's leadership deployed a regulatory strategy, based on the adoption of a group of agreements and resolutions of the political management bodies and the state, aimed at ordering the undertaking of the Energy Revolution, based on a set of principles, as well as the execution of various programs appropriate to the conditions and possibilities of economic and social development [8].

The desire for energy recovery in the country allowed the SEN to inject an electric generation capacity of 2,418 MW based on GD between diesel generators and fuel oil engines and some 6,000 emergency diesel generators have been installed in key production and service centers [8]

All this effort goes to demonstrate the essence of the social dimension of energy, translating clearly its character of social right, rather than as a market instrument at the service of private companies and state monopolies. Undoubtedly, a great effort of the country's management; but all these technologies based on oil consumption and although some advantages related to fuel consumption indicators are reported, it continues 
to involve the dedication of large economic resources to ensure its operation and maintenance, as well as the reduction of the impacts associated with the use of oil. of these technologies.

The Energy Revolution that is deepened and perfected in Cuba, is based on the conviction that sustainable development will not be possible without the rational use and saving of all kinds of resources, as well as the use of renewable energy sources that by nature own have a distributed and intermittent character.

In Cuba, the average annual value of solar energy incident on the national territory is approximately 5 $\mathrm{kWh} / \mathrm{m}^{2}$ per day. This means that every square meter of Cuban territory receives on average every day throughout the year, an amount of solar radiation equivalent to the energy content of half a kilogram of oil.

The availability of the solar resource in the Cuban territory has fostered the expectation of undertaking an accelerated takeoff in the application of energy technologies that take advantage of this renewable source, coupled with the application of programs for the development of wind energy and the use of energy. solar radiation for water heating [8].

Since previous years in Cuba, small-scale hydroelectric power has been used, water heating with solar energy, the use of wind energy for pumping water, generating electricity through autonomous photovoltaic panels, hundreds of plants small-scale biogas, cogeneration in the sugar industry, electricity generation from forest biomass and the installation of wind farms.

However, the preferential use of electricity as an energy carrier is maintained and the use of oil in generation is still considered as a priority, representing an obligated commitment of considerable economic resources in the maintenance of the current energy matrix and the support of a planning scheme centralized, which does not respond to the idea of maximizing the efficiency of the potential contained in renewable sources.

In these conditions of energy development, they have been gaining space in the field of human thought, a group of currents put forward to undertake new solutions of sustainable bias, to the old problems of the traditional energy scheme and even when some novel solutions with the application of renewable sources, there is a tendency to maintain common features of traditional energy designs.

These currents are daughters of a linear thought, which takes too far important and legitimate considerations, excluding other equally significant factors and among them, we can enunciate: "economism", "scientism" and "technology" [1].

In "economism" anthropocentrism prevails, granting little or no value to nature apart from its immediate use for obtaining economic benefits or dividends. According to this concept, there are not "rights" in the natural world that humans have the obligation to respect. It was a thought that justifies the overconsumption, depletion of natural resources given the comfort guarantees, that they report, it denies the penetration of alternative renewable energy solutions, claiming its high investment costs in relation to the nominal power of the systems, it resists deepen in detail the study and recognition of the economic impact that represents the use of these sources.

The analysis of economic results has was prioritized in the short term, it resists long-term economic planning, in other cases, the non-adoption of a legal system that regulates and promotes the introduction of renewable energies is justified, arguing that economic capacity would make it impossible to comply with the Law due to lack of resources to develop these systems.

The "scientism" gives science all the powers to solve human problems, believes that science can do the same or more than what nature has done. It downplays the methods of exploiting renewable energy sources, considering the simple, archaic and incapable of responding to the technical problems posed by the demands of energy development.

This current manifests itself very surreptitiously based on the need for technological development to provide modern and comfortable responses to society's problems. This manifestation is considered by some authors as a heresy [9], is an oversimplification of the ways in which science is related to the social and political issues of human society.

The "technology" has was closely linked to previous trends and has its origin in technological development, has was based on an irreplaceable role that has was called to play technology, facing many problems related to the environment. Considers that technologies based, on the use of renewable sources are not capable of satisfying the high demands, required by the economic and social development of humanity, becoming a dangerous current when the technological solutions found move away from science and one more wide range of values and human interests, based on the application of technologies that predator natural resources and impact the environment.

Perez, A. V., Gamez, M. R., Sera, A. S., \& Santos, R. D. (2018). Sustainable energy development: its postulates and principles in the community. International Journal of Social Sciences and Humanities, 2(2), 214-225. https://doi.org/10.29332/ijssh.v2n2.167 
The goals of sustainable development are not possible to achieve, from the old traditional energy development scheme, which has been based on the consumption of fossil fuels, with large generation centers that imply increasingly sophisticated and specific generation technologies, with a complex scheme of distribution and transportation of electricity that has associated losses, which particularizes preferentially the consumption of a type of energy, without considering other solutions and variants linked to fuel savings, the protection of natural resources and the optimal use of other territorially available sources

\subsection{Postulates and principles of sustainable energy development}

From a scenario where the rules and laws that govern the traditional energy profile prevail, it is difficult to undertake the goals of sustainable energy development with the large-scale use of renewable sources and their introduction into the national energy matrix, without putting the tools into practice. Regulatory instruments that allow ordering and regulating the gradual and progressive penetration of renewable sources in the national energy base.

It is about distinguishing the regulatory bases of two processes that coincide with the social purposes of their management and that from the technical point of view can be complemented, that is, to ensure the energy service to the tasks of the development of society; but they differ in the bases, principles, as well as the instrumental and practical concepts.

The traditional electric system is sustained in the consumption of fossil fuels to generate electricity, is based on a scheme with large and medium generation centers and a complex system of distribution and transportation of electricity to final consumption, electric service is dispensed by a Central Cargo Office and other offices in the province levels, privileges the use of electricity as energy carrier par excellence, the planning scheme responds to the concepts of centralization of generation and dispatch of energy, technological processes associated a group of environmental impacts that constitute an economic burden for the system and for the national economy.

The energy system based on the use of renewable sources, is based on the use of the potential that is dispersed in the territory, is based on a distributed scheme composed of multiple facilities that have the capacity to provide various quality energy services, It is not necessary to link the complex processes of dispatch, distribution and energy transportation. The planning scheme responds to territorial and local concepts of use of renewable sources, managing to reduce the economic burden for the system and for the country related to environmental impacts.

The analysis of the regulatory capacity required to order the process of gradual and progressive penetration of renewable sources in the country's energy base must be based on a solid theoretical platform of postulates and principles, aimed at characterizing and distinguishing the development scenario of these sources.

\subsection{Postulates of sustainable energy development [10]}

The postulates of sustainable energy development are the basis for the logical reasoning of the future energy policy, and these concepts are used to formulate the principles that should govern the penetration of technologies that take advantage of renewable sources, being able to demonstrate openness to a new way to establish a national energy base that is diverse and respectful of the laws of nature, a protector of the environment and respect for the enjoyment of a healthy and full life by future generations.

At the same time, the postulates constitute a declaration of the most general principles, which should govern the concepts of national energy planning sustained in resources available in the national territory, on the basis of achieving high self-sufficiency and minimizing the dependence on imported technologies of generation based on the consumption of fossil fuels:

a) The country can not sustain its energy development beyond the availability of resources that it has territorially.

b) Energy development has to respond to economic, social and environmental interests 
3.4 Principles of sustainable energy development [10]

The principles of sustainable energy development contain the fundamental idea on which the theory of the use of renewable sources and the energy services deriving from it is based:

The principle of public service derives from the nature of the social effectiveness of energy, the activities of generation and commercialization of renewable energy benefits, constitute public services par excellence and their protection must be exercised by the State through the authorities of the territories, as well as may be carried out by natural or legal persons according to the authorization and regulations established in the regulation.

Renewable sources of energy are distributed in quantity and quality throughout the national territory, this quality is derived from the territorial principle, the use of renewable sources, energy generation and marketing, will be made in the mode of distributed generation, that is to say to take advantage of the renewable resource where its intensity and quality allow it, consuming the energy where it is generated, which guarantees quality and efficiency in the service, at the same time that it is possible to reduce the losses that are characteristic in the centralized systems.

The Principle of energy planning, decentralized and territorial, implies that the activities of generation and commercialization of renewable energy services will be subject to planning that will be carried out by the territories under the direction of the State. Priority is given to energy generation services that contribute to the reduction of energy consumption generated by oil.

All natural and legal persons in the national territory have the right to be clients of renewable energy services according to the conditions established by regulation. All customers will receive this service in the conditions of quality and safety that are regulated and in these concepts, the principle of universal energy supply is described.

The principle of territorial technical coordination is focused on guaranteeing that the technical and operational activities of the system are coordinated with the provincial, municipal and local structures where they are located. Those related to the facilities that generate electricity and are connected to the SEN will be subject to mandatory coordination with the Cargo Dispatch, which holds its technical direction.

Despite the fact that renewable energy sources are an integral part of the natural environment and that their forms of use are not made by invasive technological methods, considering their in troduction as a contribution of environmental protection, no technology or human action is totally innocuous, so its application will be subject to the process of environmental impact assessment from the project stage, in order to minimize its effects on the environment, configuring the principle of protection and sustainable use of the environment.

The principle of territorial scientific-technical cooperation promotes the development and introduction of technologies for the use of renewable sources, through a process of study and consultation in cooperation with the scientific and technical institutions located in the localities, taking full advantage of the wide potential for existing scientific and technical knowledge, constituting a strategic task of the State in the current conditions of the country's development.

The diversity of renewable energy services that can be derived from the use of renewable sources, must be subject to a regime of differentiated rates according to the characteristics of these and in the conditions established by regulation, in compliance with the principle of differentiated rates.

The principle of territorial energy self-sufficiency is a strategic goal for the country's economy, in a globalized world where energy has become an instrument of power and hegemonic domination of world powers. The SER is based on the use of renewable sources that are available in intensity and quality at the site where the service is provided, without the need for external supply.

The nature of the SER allows these to be carried out in conditions of minimum cost, constituting in itself an effective promotion of energy savings, by converting the final consumer into an actor of the generation of service, hence the effectiveness of the principle of efficiency and energy saving. The introduction of these services constitutes a guarantee of the saving measures since the consumption of energy produced with the use of oil is reduced, reducing the expenses related to the environmental impact.

The principle of quality and internal control is a requirement for the use of renewable energy sources. The introduction of technologies that take advantage of these sources will be justified, to the extent that rigorous observance of quality standards and internal control is maintained, aimed at promoting high levels of profitability in the use of energy potentials.

Perez, A. V., Gamez, M. R., Sera, A. S., \& Santos, R. D. (2018). Sustainable energy development: its postulates and principles in the community. International Journal of Social Sciences and Humanities, 2(2), 214-225.

https://doi.org/10.29332/ijssh.v2n2.167 
In the current energy scenario all sources and potentials must be combined in order to adopt the most appropriate technological variant. The principle of energy complementarity is based on ensuring the energy services demanded by society, through efficient use of each of the available sources, privileging the use of them based on the availability of resources that are possessed, achieving the optimal combination, efficient and profitable from the energy, economic and environmental points of view.

\section{Conclusion}

From the analysis of the historical evolution of the energy profile in Cuba, it is evident the need to articulate the legal regulatory framework that makes valid the postulates and principles that should distinguish sustainable energy development and the management of the use of renewable energy sources, as well as its introduction into the country's energy matrix.

\section{Conflict of interest statement and funding sources}

The authors declared that they have no competing interest. The study was financed by the authors.

\section{Statement of authorship}

The authors have a responsibility for the conception and design of the study. The authors have approved the final article.

\section{Acknowledgments}

The authors thank the editor team for their consideration to publish the article in IJSSH. 


\section{References}

1. Antonio, V.P. (2012). Los Sistemas que aprovechan las Fuentes Renovables de Energía, desde una visión jurídica. Tesis de grado: Licenciado en Derecho. Universidad de Oriente. Cuba.: p. 47,48 y 49.

View in (Website)

2. Antonio, V.P., Maria Rodríguez. (2013). Una visión jurídica dirigida a los Sistemas que aprovechan las Fuentes Renovables de Energía en Cuba. Monografias.com.

View in (Website)

3. Arrastía Ávila, M. A. (2006). Hacia la formación de un nuevo paradigma energético en la escuela y la sociedad cubana.

View in (Google Scholar)

4. Colectivo, D. (2000). Autores: Derecho Ambiental Cubano. Editorial Félix Várela. Cuba.

View in (Google Scholar)

5. Cuba., C.d.M.d.l.R.d. (1975). Ley Eléctrica No 1287. Gaceta Oficial de la República de Cuba. Edición ordinaria.: p. 3 páginas.

View in (Website)

6. Figueredo, C.M. and A.M. Larrosa. (2010). La sociedad cubana y su contexto energético. Vía para el logro del desarrollo sostenible. Solarización Territorial. (ISBN 978-959-7113-39-3): pp. 65-80.

View in (Website)

7. Gómez., A. (2004). 120 años de electricidad en Cuba. . Una mirada técnica hasta el siglo XX, desde la mirada futurista de Martí.

View in (PDF)

8. Rincón, M. A. P. (2007). Comercio internacional y medio ambiente en Colombia: mirada desde la economía ecológica. Universidad del Valle.

View in (Google Scholar)

9. Quisbert, E. (2009). Sujetos y partes procesales.

View in (Google Scholar)

10. López Regalado, S. (2017). Estudio de diagnóstico para la implementación de una edificación hidrosustentable Etapa de Anteproyecto (Doctoral dissertation, Universidad Tecnológica de La Habana José Antonio Echeverría).

View in (Google Scholar)

11. Santamarta, J. (2004). Las energías renovables son el futuro. World Watch, 22(3440.16).

View in (Google Scholar)

12. Ramos, J. L. M., Pérez, A. V., Gámez, M. R., \& Zambrano, R. V. H. (2018). Renewable energy sources on the change of energy matrix in Manabí province. International Research Journal of Engineering, IT and Scientific Research (IRJEIS), 4(4), 17-29.

View in (Google Scholar)

13. Gámez, M. R., Pérez, A. V., Será, A. S., \& Ronquillo, Z. M. (2017). Renewable Energy Sources and Local Development. International Journal of Social Sciences and Humanities (IJSSH), 1(2), 10-19.

View in (Google Scholar)

Perez, A. V., Gamez, M. R., Sera, A. S., \& Santos, R. D. (2018). Sustainable energy development: its postulates and principles in the community. International Journal of Social Sciences and Humanities, 2(2), 214-225.

https://doi.org/10.29332/ijssh.v2n2.167 
14.Cedeño, M. L. D., Arteaga, M. G. D., Pérez, A. V., \& Arteaga, M. L. D. (2017). Regulatory Framework for Renewable Energy Sources in Ecuador Case Study Province of Manabí. International Journal of Social Sciences and Humanities (IJSSH), 1(2), 29-42.

View in (Google Scholar) 


\section{Biography of Authors}

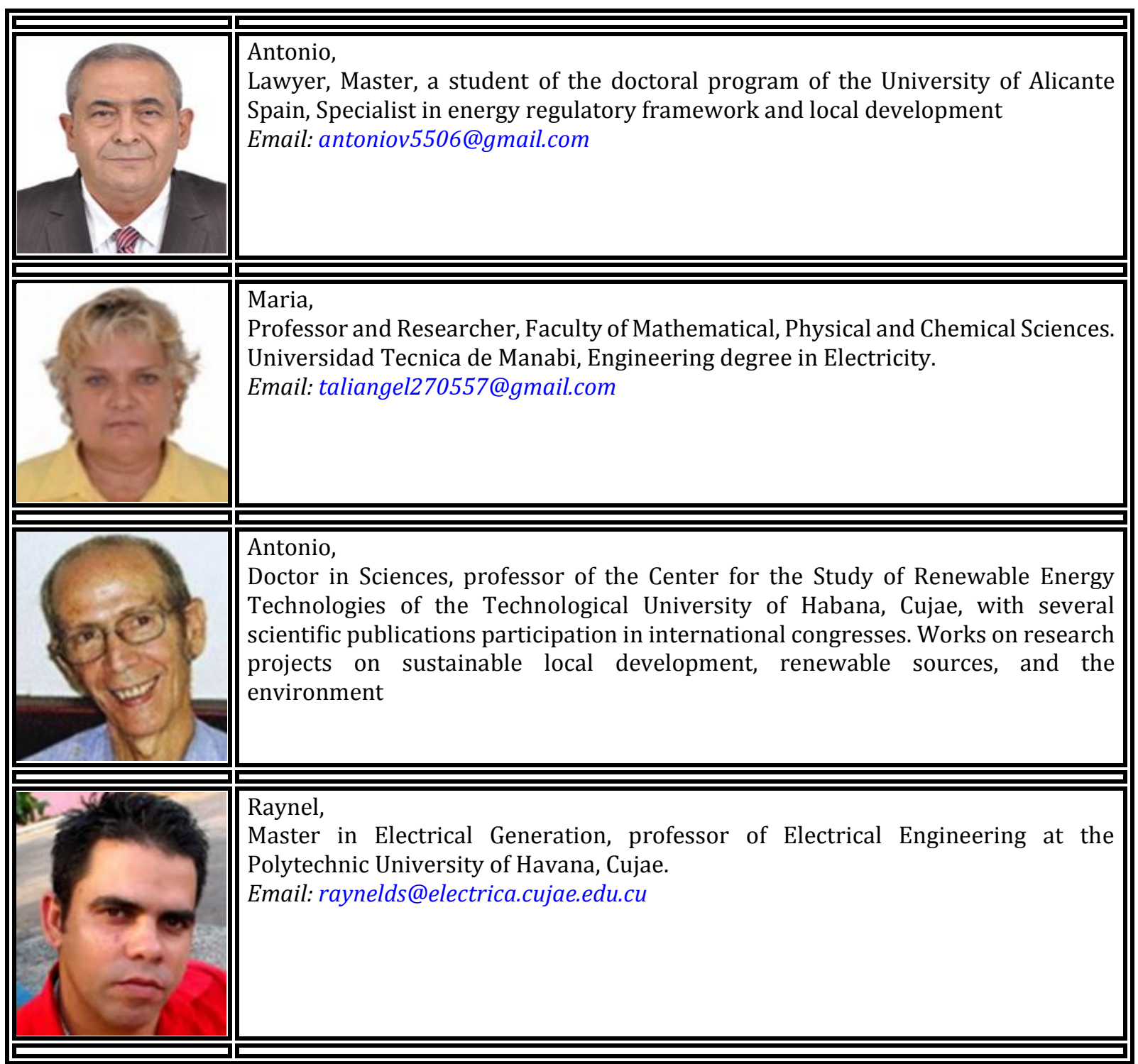

Perez, A. V., Gamez, M. R., Sera, A. S., \& Santos, R. D. (2018). Sustainable energy development: its postulates and principles in the community. International Journal of Social Sciences and Humanities, 2(2), 214-225. https://doi.org/10.29332/ijssh.v2n2.167 